ブタの初乳による抗体スクリーニング検査法の検討

小川秀治 伊藤 隆 佐藤 行 鎌田久祥 安田 有 渡部 満

秋田県南部家畜保健衛生所

\title{
Antibody Screening by the Use of Sow Colostrum
}

\author{
S. Ogawa, R. Itoh, A. Satoh, H. Kamada, Y. Yasuda and M. Watanabe
}

Akita Prefecture Southern Region Livestock Hygiene Service Center

要 約 分娭後における乳清及び血清中免疫グロブリンG（IgG）濃度、豚萎縮性鼻炎 (AR)、豚 丹毒 (SE) 凝集抗体価の経時的推移を、母豚24頭を用いて調査した。乳清中IgGは、分婏 0 日が最も高 く、42.5 mg/ml と血清 $I g G の$ 約 3 倍の值を示した。この後16日までは血清と同レベルで推移し、以降低下 し20日で血清の半分になった。乳清中のAR抗体およびSE抗体は、それぞれ分娩後20日、分婏後10日ま で検出可能であった。豚オーエスキー病ラテックス凝集抗体を、ワクチン接種豚の乳清38検体、未接種 豚の乳清23検体を用いて調査した。ワクチン接種豚の乳清中抗体は分娩 0 日の 9 検体全てが陽性を示し、 10 日後の 2 検体も陽性を示した。酵素抗体法（ELISA）検査では、凝集抗体陽性の検体は全例ワクチ ン抗体と判断された。未接種豚の乳清 23 検体は全て抗体陰性であった。なお、野外抗体陽性 6 例の検査 では、乳清中の抗体は血清と同じく野外抗体と判断された。

初乳は血清と同様の抗体検査が可能であり、初乳を用いた抗体検査は繁殖母豚群の抗体スクリーニン グや疾病清净化に向けて有効な方法と考えられた。

一キーワード：豚、初乳、乳清、抗体検査、オーエスキー病

家畜臨床誌２9(1):1-5, 2006

ABSTRACT Postpartum changes in the immunoglobulin $\mathrm{G}$ (IgG) concentration and the agglutination antibody titers of swine atrophic rhinitis (AR) and swine erysipelas (SE) in whey and serum were studied in 24 sows. The whey $\operatorname{IgG}$ was highest $(42.5 \mathrm{mg} / \mathrm{ml})$ immediately after farrowing (Day 0), when its concentration was 3 times that in the serum. The IgG concentration decreased to the same level as that of the serum by Day 16 and to half the serum concentration by Day 20. AR antibody and SE antibody could be detected in the whey, respectively, until Day 20 and Day 10. The latex agglutination antibody of Aujeszky's disease was studied in 38 whey samples collected from vaccinated sows and 23 samples from unvaccinated sows. Nine out of 9 samples on Day 0 from vaccinated sows were antibody positive and $2 / 2$ samples on Day 10 were positive. ELISA confirmed that all the latex agglutination antibodies detected in the samples were vaccine antibodies. Antibody was not detected in 23 whey samples collected from unvaccinated sows. Examination of 6 antibody-positive cases observed in the field showed that the antibodies both in the whey and the serum had been induced by field infection. It was possible to detect antibodies effectively with colostrum, as with serum, and it appeared that colostrum antibody testing could become an effective means for the antibody screening of breeding sows and for maintaining them disease-free.

Key Words : swine, colostrum, whey, antibody, Aujeszky's disease

Jpn. J. Vet. Cinics 29(1):1-5, 2006

Received 5 October 2005/ Accepted 31 January 2006

* Correspondence to S. Ogawa, Akita Prefecture Southern Region Livestock Hygiene Service Center, 6-55 Fujimicho, Daisen, 014-0011, Japan（T014-0011 大仙市富士見町6-55） 


\section{緒 言}

母豚の抗体スクリーニングは農場の疾病対策に有効で あるが、そのための採血は豚へのストレスや事故などの 眯念から農家が難色を示すことがある。また、農場への 立入制限、採血の時期などの制約があり、血液による抗 体検査は容易ではない。

初乳中には血清と同等以上の免没グロブリンが存在し ていることが知られている $[11]$ 。今回我々は初乳中の 免疫グロブリンに着目し、乳汁を検体とした抗体検查の 可能性について検討を行った。検討項目は、乳汁処理方 法、分娩後の乳清と血清における免疫グロブリン $\mathrm{G}$ (IgG) 濃度、豚萎縮性鼻炎（AR）及び豚丹毒 (SE) 凝 集抗体価の経時的変化の比較、乳清による豚オーエスキー 病 (AD) 抗体の検出、䤃素抗体法（ELISA）に上る乳 清中の豚繁殖・呼吸器障害症候群 (PRRS) 抗体検出、 の 4 項目である。

\section{材料および方法}

1) 材料

12戸の養豚農家から母豚の乳汁と血液を採材した。検 查材料として、母豚48頭から採取した分娩 0 日から分娩 後20日までの乳汁 61 検体と母豚24頭の分婏 0 日から分婏 後20日までの血液29検体を供試した。また、AD野外抗 体陽性の母豚から採取した血液および乳汁 6 検体につい て $\mathrm{AD}$ 抗体検出を試みた。血液は $20^{\circ} \mathrm{C} 、 2,500$ 回転/分で 10分間遠心することにより血清を回収し、抗体検査に供 した。

検体採取農家における母豚へのワクチン接種状況は ARが10戸で分娩前 4 週と 2 週に、SEが12戸で年 2 回、

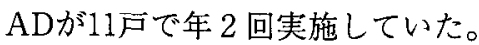

2 ) 乳汁処理方法

乳汁中の免疫グロブリンは、乳汁から脂肪とカゼイン
を除去した乳清中のタンパク質に含まれる [13]。そこ で、検体は脱脂のみを行った乳清で良いのか、肉眼的に 透明な乳清まで処理する必要があるかについて検討した。

乳汁から脱脂乳を採取するため、 $4{ }^{\circ} \mathrm{C} 、 12,000$ 回転 分で30分遠心した。さらに、脱脂乳から透明な乳清を得 るため、カゼイン除去を実施した。カゼイン除去は、凝 乳酵素レンネットによるカゼイン凝固法（レンネット姏 理）と $5 \mathrm{~N}$ 塩酸添加による酸処理法によって実施した。 レンネット処理は、脱脂乳にレンネットを加えて濃度 2.86、 $9.52 \mathrm{ng} / \mathrm{ml}$ の 2 濃度に調整し、 $35^{\circ} \mathrm{C}$ の恒温漕で、 30 分反応後、 $4{ }^{\circ} \mathrm{C} 、 12,000$ 回転/分で30分間遠心するこ とにより、乳清を回収した。塩酸処理は乳汁にpH4.0〜 4.5 になるように塩酸を添加後、 $4{ }^{\circ} \mathrm{C} 、 12,000$ 回転/分で 30分間遠心することにより乳清を回収した。使用乳汁は、 分婏 0 日に得た初乳 2 検体（AおよびB）を使用した。

3) 抗体検査方法

IgG濃度は、ブタIgGプレート（細菌化学研究所, 仙 台）を用いて、一元放射免疫拡散法により行った。 $\mathrm{AR}$ の凝集抗体洒、SEの凝集抗体価はそれぞれAR抗原「北 研」(北里研究所, 埼玉)、日生研アグテックSE抗原 (日生研，東京）を用いて测定した。 $\mathrm{AD} ラ$ ラテックス 凝集抗体は、AD抗原ラテックス「ゼンノウ」(バイラ ルアンチゲン社，米国）を用いて、検査した。ADおよ びPRRSのELISA検査は、それぞれADV（gI）エリーザ キット (アイデックスラバラトリーズ，米国)、PRRSエ リーザキット（アイデックスラバラトリーズ，米国）を 用いた。

\section{結 果}

\section{1) 乳汁好理方法}

豚の乳汁処理結果を表 1 に示した。レンネット処理で は透明な乳清が濃度 $9.52 \mathrm{ng} / \mathrm{ml}$ のみで得られた。塩酸処

表 1 乳汁処理結果

\begin{tabular}{|c|c|c|c|c|c|c|}
\hline 処理方法 & $\begin{array}{c}\text { 濃度 · 乳汁 } \\
\text { pH } \\
\end{array}$ & $\begin{array}{l}\text { 供試 } \\
\text { 材料 }\end{array}$ & $\begin{array}{l}\text { 乳精 } \\
\text { 透明度 }\end{array}$ & $\begin{array}{c}{ }^{* 1} \mathrm{IgG} \text { 濃度 } \\
(\mathrm{mg} / \mathrm{ml})\end{array}$ & ${ }^{* 2} \mathrm{AR}$ 抗体価 & ${ }^{* 3} \mathrm{SE}$ 抗体価 \\
\hline \multirow{4}{*}{ レンネット } & 2.86 & $\mathrm{~A}$ & 混濁 & 29.61 & 1280 & 32 \\
\hline & $\mathrm{ng} / \mathrm{ml}$ & B & 混濁 & 42.00 & 2560 & 32 \\
\hline & 9.52 & A & 透明 & 29.61 & 1280 & 32 \\
\hline & $\mathrm{ng} / \mathrm{ml}$ & $B$ & 透明 & 40.74 & 2560 & 64 \\
\hline \multirow{4}{*}{ 塩 酸 } & \multirow{2}{*}{ ph $\quad 4.5$} & A & 混濁 & 24.36 & 1280 & 32 \\
\hline & & B & 混濁 & 25.70 & 2560 & 64 \\
\hline & \multirow{2}{*}{ ph 4.0} & A & 凝固 & - & - & - \\
\hline & & B & 凝固 & - & - & - \\
\hline \multirow{2}{*}{ 脱 脂 } & & A & 混濁 & 25.20 & 1280 & 64 \\
\hline & & B & 混濁 & 39.06 & 2560 & 64 \\
\hline
\end{tabular}

${ }^{* 1} \mathrm{IgG}$ : 免疫グロブリン $\mathrm{G},{ }^{* 2} \mathrm{AR}$ : 豚萎縮性鼻炎, ${ }^{* 3} \mathrm{SE}:$ 豚丹毒 
理では、脱脂乳 $800 \mu 1 に 5 \mathrm{~N}$ 塩酸 $10 \mu$ は添加することで カゼインが㠜固する $\mathrm{pH} 4.5 か ゙$ 得られたが、透明な乳清は 回収できなかった。そこで、添加量を $20 \mu 1$ としたとこ ろ乳汁全体が㠜固し、乳清は得られなかった。

IgG濃度はレンネット处理に比べ、塩酸処理で低下す る傾向がみられた。抗体価ではAR、SEとも処理方法に よる大きな変化はみられなかった。

2）乳清と血清におけるIgG濃度、AR、SE凝集抗体価 の分娩後経時的変化の比較

乳汁処理方法を比較した結果、最も簡易な脱脂処理で も抗体検查が実施可能であることが示唆された。そこで、 脱脂のみを行った乳清中IgG濃度の分娭後の経時的変化 を測定した。分婏 0 日の乳清IgGは $42.5 \mathrm{mg} / \mathrm{ml}$ で、分婏 0 日の血清IgGの約 3 倍の高い值を示した。以後、減少 し6 日以降では血清と同等濃度で推移、17日以降は血清 より低值、20日では血清の約半分となった（図 1)。

乳清中AR抗体価にばらつきはみられるが、分婏後10 日までは血清AR抗体価より高値を示し、11日以降16日 まで血清と同等濃度で推移し、17日以降は血清より低值 となった（図 2)。

乳清中SE抗体価は分婏 0 日で血清SE抗体洒より高值 を示した。その後減少し、分浼11日以降抗体は検出され なかった（図 3 )。

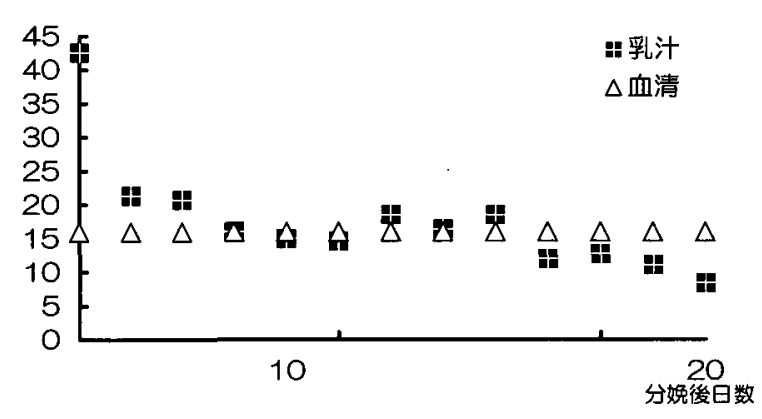

図 1. 分婏後の免疫グロブリン濃度の変化
3) 乳清によるADラッテクス凝集抗体の検出

$\mathrm{AD}$ ワクチン接種の母豚38頭、未接種の母豚23頭から 得られた乳清および血清についてラテックス凝集抗体検 査とELISA検查を実施した。また、AD野外株陽性豚 6 頭から得られた乳清および血清について、同じ検查を行っ た。

(1)ADワクチン接種豚の検査

ラテックス凝集抗体検查では分婏 0 日の乳清は 9 頭全 て陽性であった。これ以降、分婏後11日まで凝集がみら れ、19日では凝集陰性であった。ELISA検査では分婏 0日から19日までの乳清全てに、ワクチン抗体が検出さ れた。なお、血清では全ての個体にワクチン抗体が検出 された (表 2 )。

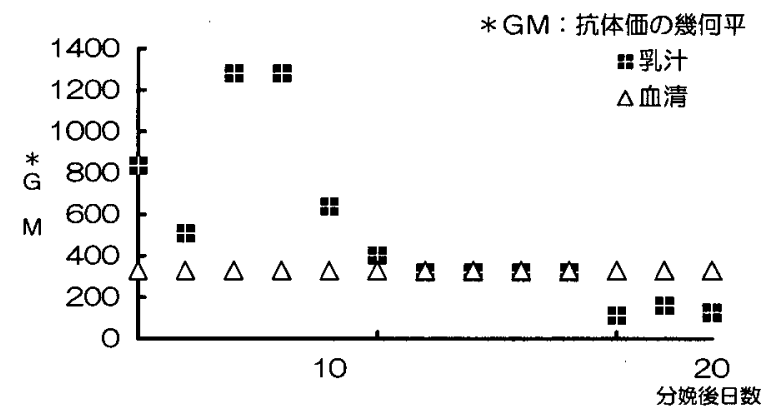

図 2 . 分婏後の豚萎縮性鼻炎抗体価の変化

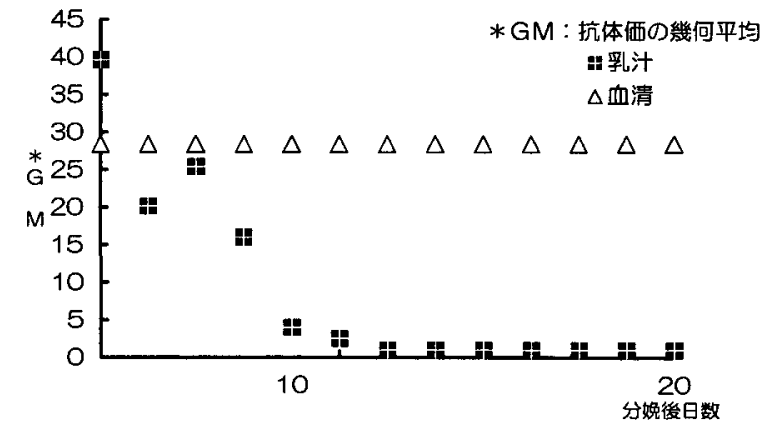

図 3. 分娩後の豚丹毒抗体価の変化

表 $2 A D$ 検查結果

\begin{tabular}{|c|c|c|c|c|}
\hline \multirow[t]{2}{*}{ 分婏後日数 } & \multicolumn{2}{|c|}{$\begin{array}{l}\text { ラテックス凝集抗体 } \\
\text { 陽性検体／検查検体 }\end{array}$} & \multicolumn{2}{|c|}{$\frac{\text { ELISA }\left(^{* 2} \mathrm{gI}^{-}\right)}{\text {陽性検体 } / \text { 検查検体 }}$} \\
\hline & 乳汁 & 血清 & 乳汁 & 血清 \\
\hline 0 & $25 / 25$ & $9 / 9$ & $25 / 25$ & $9 / 9$ \\
\hline 1 & $5 / 5$ & & $5 / 5$ & \\
\hline 2 & $4 / 4$ & & $4 / 4$ & \\
\hline 9 & & $1 / 1$ & & $1 / 1$ \\
\hline 10 & $2 / 2$ & $2 / 2$ & $2 / 2$ & $2 / 2$ \\
\hline 11 & $1 / 1$ & $1 / 1$ & $1 / 1$ & $1 / 1$ \\
\hline 19 & $0 / 1$ & & $1 / 1$ & \\
\hline 29 & & $1 / 1$ & & $1 / 1$ \\
\hline "!未接種豚 & $0 / 23$ & $0 / 15$ & & \\
\hline
\end{tabular}


(2)ADワクチン未接種豚の検査

ラテックス凝集抗体検查で乳清、血清ともに抗体は検 出されなかった（表 2 )。

(3)AD野外株陽性豚の検査

全例において乳清、血清ともラテックス凝集反応陽性 で、ELISA検査によって野外株陽性と判断された。

4) 乳清によるPRRS抗体の検出

PRRS抗体検査は同一個体の乳汁22検体と血清22検体 についてELISA検查を実施した。抗体陽性は 8 頭、陰 性は14頭で、同一個体から採取した血清と乳清の抗体検 查結果は、陽性、陰性共にすべて一致した。

\section{考察}

今回、初乳に含まれる免疫グロブリンに着目し、乳汁 による抗体検査の可能性を検討した。

豚の乳汁を脱脂のみの処理を行った検体、酵素あるい は酸処理によって透明な乳清を得た検体について、IgG 濃度及び抗体価を比較したが大きな差はみられなかった。 実際の乳汁処理作業は、行程の少ない脱脂のみによる前 処置が適していると考えられた。

分娩後のIgG濃度および抗体の経時的変化を調査した ところ、分婏 0 日の乳清IgG濃度は血清の約 3 倍で分娩 後16日まで血清と同等、20日で血清の約半分であった。 分婏 0 日でのIgG濃度に多少の差はみられたが、斎藤ら [10］、室伏ら［5］の報告と同様の動態が確認された。 抗体価については、ARとSEについて調査を行った。乳 清抗体価は分婏 0 日でそれぞれの血清抗体価に比較して 著しい高值を示し、分娩後日数の経過とともに減少した。 概ね分娩後10日までの乳汁で、AR、SEの抗体検査は可 能と考えられた。

$\mathrm{AD}$ ワチン接種豚の抗体検査では、分婏後11日まで 凝集抗体陽性を示した。しかし、分娩後19日で凝集抗体 は検出されなかった。同一検体のELISA検查で、検查 を実施した乳清全例にワクチン抗体が検出された。これ らの所見は血清を用いた抗体検査と同一の結果であった。 また、ワクチン未接種豚のAD検査により、血清抗体陰 性の豚には乳汁中抗体が検出されないことが確かめられ た。乳汁によるAD検査は分婏 0 日であれば全例で抗体 が検出され、少なくとも分婏後10日までの乳汁で検査可 能と考えられた。なお、AD血清抗体と乳清抗体の一致 はワクチンによるもの、野外株による抗体を問わず同一 の結果であった。加藤［1］は滤紙に吸着した初乳の抽 出液を用いてADのELISA検查を実施し、初乳を用いた $\mathrm{AD}$ 検査の有用性を報告している。今回我々の用いた検
体は、乳汁を脱脂処理したのみの乳清である。加藤 [1] の処理に比較して検体を得るための前処置は簡易であり、 当初僰念されたラテックス凝集反応の見づらさは感じら れなかった。

PRRS検査で陽性豚 8 頭、陰性豚14頭で、同一個体か ら採取した血清と乳清の抗体検査結果は、陽性、陰性共 に全て一致した。乳清でのPRRS抗体の検出は可能であ り、母豚の疾病スクリーニングとして乳汁を用いること は有用であると考えられた。

乳汁を用いての抗体スクリーニング検查は、乳清中の IgG濃度、抗体価の分娩後の推移を検討した結果、乳汁 を用いての抗体検查は分婏 0 日の乳汁、すなわち初乳を 検体とするのが精度のうえで最も確実であると考えられ た。また、採材にあたって分婏 0 日の採材が最も容易で あった。この時期の母豚は十分量の移行抗体を子豚に与 えるため産乳量が豊富で、ほとんど起立しないため採材 に要する時間は短く、母豚に対するストレスは極めて少 ないものと考えられた。初乳を使用した抗体検査は、疾 病スクリーニングなどを目的にActinobacillus pleuropneumoniae [2,6]、Mycoplasma hyopneunomiae [3,7 - 9,12]、Pauteurella multocida [4] などについ ての報告が見られる。フィンランドではFinnish Pighealth Schemeによって初乳を農家が採材し、それぞれ の疾病の没学調査や根絶計画の策定に用いられている [2-4,8,9]。フィンランドでの一連の報告のなかで Levonen [3]は Mycoplasma hyopneunomiaeについ て185戸6,256例の初乳サンプルを調查した結果、初乳中 の抗体は臨床症状発現の 6 か月前に検出可能で、臨床症 状発現時の血清抗体陽性率は $10.9 \%$ に止まっていたとし、 初乳を用いた抗体検査の優位性について強調している。 我々の調査では分娩後経過について詳細な時間は記録し ていないが、Rautiainenら [8] は分婏 2 時間以内の初 乳中抗体はその後に採材したそれに比べ 3 倍高いと報告 している。

以上のことから、初乳による抗体検査は血清と同様の 検査が可能で、採材も容易であることから母豚へのスト レスも少なく、農家の理解を得やすいと考えられた。さ らに、農家自身が採材可能で保存も容易である。乳汁に よる抗体検查は、疾病スクリーニングや疾病清浄化に向 けて有効な方法のひとつであり、各種疾病の浸潤調査や 対策に有効的に活用を図りたい。 


\section{文 献}

1 加藤多喜雄 (1986). 初乳吸着滤紙を㭘查材料とし たELISAによるオーエスキー病の抗体検查. 日本の 養豚 35: 40-45.

2 Levonen, K., Veijalainen, P. and Seppanen, J. (1994). Actinobacillus pleuropneumoniae serotype2 antibodies in sow colostrum in Finnish pighealth-scheme herds. Zentralbl Veterinarmed B 41: 567-573.

3 Levonen,K., (1994). Detection of enzootic pneumonia in pig herds using enzyme-linked immunosorbent assay in sow colostrum. Res. Vet. Sci. 56: 11-113.

4 Levonen, K., Frandsen, P. L. and Seppanen, J. (1996). Detection of toxigenic Pasteurella multocida infections in swine herds by assaying antibodies in sow colostrum. J. Vet. Diagn. Invest. 8: 455-459.

5 室伏淳一, 松本浩二, 河原崎達雄 (1999). SPF豚 におけるIgG値の推移. 静岡中小試研報 10: 19-22.

6 Nielsen, R. (1995). Detection of antibodies against Actinobacillus pleuropneumoniae, serotype 2 in porcine colostrum using a blocking enzyme-linked immunosorbent assay specific for serotype 2 . Vet. Microbiol. 43: 277-281.

7 Rautiainen, E. (1998). The prevalence of Mycoplasma hyopneumoniae in pig herds in western Finland based on the demonstration of antibodies in colostrum by ELISA. Acta Vet. Scand. 39: 325-330.

8 Rautiainen, E., Tuovinen, V. and Levonen, K. (2000). Monitoring antibodies to Mycoplasma hyopneumoniae in sow colostrum - a tool to document freedom of infection. Acta Vet. Scand. 41: 213-225.

9 Rautiainen, E., Oravainen, J. and Virolainen, J. V. (2001). Regional eradication of Mycoplasma hyopneumoniae from pig herds and documentation of freedom of the disease. Acta Vet. Scand. 42: 335-364.

10 斎藤至是, 真田 武, 岩崎 孝 (1986). 母豚乳汁 および哺乳子豚血清のIgG, IgM, IgAの動態について。 日畜会報 57: 349-351。

11 清水悠紀臣（1981）。感染症と母子免疫:獣医領域に 抢ける免疫学. 第1版. 553-563, 近代出版, 東京.
12 Wallgren, P., Bolske, G. and Gustafsson, S. (1998). Humonal immune responses to Mycoplasma hyopneumoniae in sows and offspring following an outbreak of mycoplasmosis. Vet. Microbiol. 60: 193205.

13 山本邦男 (1978). 牛乳：畜産大事典. 第4 版. 945957, 養賢堂, 東京. 